\title{
Research Paper Economics of marketing of paddy in Gondia district of Maharastra
}

See end of the paper for authors' affiliations

Correspondence to :

K.H.

PARASHURAMKAR

Agricultural Economics and Statistics Section,

College of Agriculture, NAGPUR (M.S.) INDIA

Paper History :

Received : 24.03 .2014 ;

Revised : 25.06.2014;

Accepted: 13.07 .2014
G.H. PARSHURAMKAR, A.S. DAREKAR, S.B. DATARKAR AND U.T. DANGORE

ABSTRACT : Paddy (Oryza sativa L.) is the world's second important food crop after wheat because of yield potential and highly nutritive value. India ranks $2^{\text {nd }}$ in area as well as production after China. Gondia district is agriculturally developed district whcih may be because of the monocrop paddy. Gondia district is historically important for the cultivation of paddy crop. Practically the entire agricultural population is either directly or indirectly dependent on the success of this crop. The study was undertaken in Gondia district with objective were to study the cost and return of marketing of paddy and problems faced by farmers in marketing of paddy. The results pertained on primary data collected through survey method from Gondia district for the year 201011. For the study, 90 paddy growers were selected. For, the study four marketing channels were selected for knowing the market price spread. Channel (I) - Producer-Consumer, Channel (II) -Producer-Miller-RetailerConsumer. Channel (III) -Producer- Village trader- Miller- Retailer- Consumer, Channel (IV) -ProducerWholesaler- Miller- Retailer-Consumer. Out of four-channels, producer's share in consumer's rupee was highest in case of channel (I) and it was 94.66 per cent, in channel (II) and channel (III) it was 53.05, and 53.90 per cent and in channel (IV) it was 51.87 per cent. It was concluded that the selling of produce in market by producer himself directly to the consumer was found to be most profitable. In marketing of paddy, non-remunerative price of paddy and high cost of transportation were identified to be the major problems, which need the immediate attention of the policy-makers.

KEY WORDS : Paddy marketing, Market margin, Price spread

HOW TO CITE THIS PAPER : Parashuramkar, K.H., Darekar, A.S., Datarkar, S.B. and Dangore, U.T. (2014). Economics of marketing of paddy in Gondia district of Maharastra. Internat. Res. J. Agric. Eco. \& Stat., 5 (2) : 160-165. 